\title{
"No Sunday Business": Navigating Religious Rules and Business Opportunities in the Shipyard Mennonite Settlement, Belize
}

\author{
Carel Roessingh ${ }^{1}$ \\ Associate Professor \\ Faculty of Social Sciences, Department of Organization Sciences \\ Vrije Universiteit Amsterdam \\ Daniëlle Bovenberg ${ }^{2}$ \\ Junior Lecturer \\ Faculty of Social Sciences, Department of Organization Sciences \\ Vrije Universiteit Amsterdam
}

\begin{abstract}
Within the Old Colony Mennonite settlements of Belize, the relationship between religious and economic practices entails a constant navigation of the acceptable, where threats of worldliness come from technology and from contact with outsiders. This paper takes as its focus the business of a butcher in Shipyard settlement, whose daily work testifies to a navigation of both of these potential threats. This entrepreneur uses technologies of energy, transportation, and communication - operated in part by an outside worker - to extend the radius of his meat business. The tense environment of Shipyard's religious diversity frames our discussion of these observations, leading us to reconsider our understanding of the Ordnung and its relation to business activity. To understand the entrepreneur's skillful navigation of rules and opportunities, we use the term "social capital" (Bourdieu 1986; Portes 2010) to reflect on the paradoxical relationship between religious rules and entrepreneurial space - and to consider how the Ordnung can be seen as a spacious (rather than a constrictive) place for Mennonite entrepreneurs.
\end{abstract}

\section{Keywords}

Belize; Old Colony Mennonites; Entrepreneurship; Technology; Business; Social capital

\section{Acknowledgements}

The authors would like to thank Peter Margesson for some corrections and insightful comments on an earlier draft. 


\section{Introduction}

Business practices, technology use, and religious values have proven to be compatible realities for Mennonite communities and other plain Anabaptist groups (Ems 2014; Kraybill and Olshan 1994; Turner 2014). Despite the stereotypes that their separation from the world inspires, plain Anabaptist businesspeople vary in the types of technology they use and the extent to which they use it. Exactly how and why these combinations are made by plain Anabaptists remains a matter of curiosity to outsiders, to be probed by settlement and time (Driedger 2000; Loewen 2016; Redekop, et al. 1995; Scott and Pellman 1990; Zimmerman Umble 1996).

Research often relates technology use to the community's living rules, its Ordnung. In deciding on a community's Ordnung, ministers must consider the values that the community wishes to uphold and weigh out technology's potential threat (as an envoy of worldliness) to those values. Rules about technology use are thus reflections of the particular world in which a Mennonite community is situated, the inner world of the community's religious relations and the outer world of the marketplace. Alongside this emphasis on the importance of the contextual nature of technology use, recent discussions have centered on examples from North America, and on pressures from the marketplace that require businesspeople to adapt (Ems 2014; Turner 2014). This paper explores Anabaptist business practice in another setting: a butcher shop in the Shipyard Old Colony Mennonite settlement of Belize, Central America. Studying Mennonite technology use by the Old Colony Mennonites in Belize offers an additional perspective on technology use among the plain Anabaptists.

After introducing Belize, Shipyard, and the Old Colony, we refer to recent literature on Anabaptist technology use in order to set up the ideas of Ordnung and its relation to the selective use of technology (Kraybill 2010; Roessingh and Boersma 2011; Zimmerman Umble 1996). We then describe the butcher's work - specifically his use of energy, communication, and transportation technologies - analyzing the relationship between his business practices and the Ordnung. As we document how this butcher prepares and distributes his meat, we employ the idea of social capital (Bourdieu 1986; Portes 2010) to account for the entrepreneurial space he creates for his business. We reflect, then, on how the Ordnung can be seen as both a spacious and restrictive place for entrepreneurs. Describing the butcher's work in terms of social capital draws attention to the double nature of religious rules: to limit business practice while also making extensions of the rules possible.

\section{The Mennonites and their entry into Belize}

Belize - previously "British Honduras"-is a former colony of Britain that received independence on September 21, 1981. Belize is not a very rich country. Its labor force is the smallest of Central American countries and natural resources are scarce. Consequently, the government has needed to explore other economic possibilities. One possibility involved negotiations in the 1950s with Mennonite farmers living in Mexico, inducing them to come to 
Belize for their skill at cultivating land (Roessingh and Plasil 2009). At the time, the Mennonites in Mexico were threatened with being incorporated into the Mexican social security system (Plasil 2015). As a result - and with concerns about safety, resources, and land in Mexico, and a desire to remain connected to extended family already in Belize (Loewen 2016) — several successive groups of Mennonites searched for another homeland, somewhere they could live according to their rules and beliefs.

They found such a place in British Honduras. An agreement was signed in 1957, leading to the migration of several Mennonite groups: the Old Colony, Sommerfelder, and Kleine Gemeinde (Driedger 1958; Everitt 1983; Loewen 2013; Sawatzky 1971). The Mennonites were granted freedom to administer their own colonies in exchange for producing food for the local market and export (Sawatzky 1971). In 1958, the first group of Old Colony Mennonites from Mexico arrived, settling in Blue Creek in the Orange Walk District (Everitt 1983; Sawatzky 1971). In the same year, another group from Mexico, the Kleine Gemeinde Mennonites, settled at Spanish Lookout in the Cayo District (Koop 1991; Loewen 2006; Quiring 1961). Since their migration in 1958, the number of Belizean Mennonites has grown to over 10,000 in 2015, spread over 13 settlements. They have established a strong and stable economic presence within the country through agriculture and trade (Roessingh and Schoonderwoerd 2005).

The Mennonites who settled in Blue Creek were members of the Old Colony Mennonite Church, which emerged due to a schism in the Mennonite settlements in Canada. Kroeker (2005) and Quiring (2003) point out that the name "Old Colony" derives from the Chortitza Colony in southern Russia, the oldest colony of the Mennonites in Russia. Eventually, the name Old Colony was used by outsiders to refer to "those people who were loyal to a rigid belief-system and a traditional way of life, and was adopted consequently by the members themselves" (Redekop 1969, 10). They are one of the more traditional Mennonite branches (Anderson 2013). After a schism in the Old Colony Church in Blue Creek over technology use, the more conservative members left Blue Creek and established the Shipyard settlement some 25 kilometers eastwards.

\section{The Ordnung and Technology Use}

Each Mennonite community shares a system of attitudes and behavior, typically connected to concepts such as "Gelassenheit," or the submission to the will of God, which shows itself in values like obedience, humility, and simplicity. The Ordnung is the (often unwritten) system that contains these common rules and disciplines (Kraybill and Bowman 2001; Plasil and Roessingh 2006; Scharinger-Plasil 2004). The Ordnung applies to many areas of daily life, functioning as a collective understanding that "encompasses issues related to moral behavior, dress, participation in the larger society, and selective ownership of technology," forming for many "simply the taken-for-granted way of life taught by the church and expected of faithful and virtuous members" (Kraybill 2010, 161). Guidance from the Ordnung is especially pertinent in situations where a clear-cut biblical teaching is not present (Scharinger-Plasil 2004). 
Because there is no central Old Colony church, rules are determined and maintained locally, by church elders. Consequently, there is a variety in the details of the Ordnung among churches within the Old Colony and Anabaptist groups generally along a continuum from orthodox to progressive (Hawley 1995) The Ordnung is described as a product of lengthy and repeated discussion among ministers (Gingerich 1986). Scholars have described the Ordnung as a living document, its restrictions on technology as socially constructed (Ems 2014), and there are examples of the Ordnung being altered or negotiated (Gingerich 1986; Kraybill 2010).

In cases when the Ordnung is adapted, considerations of worldliness figure prominently. Loewen (1993) explains how "the search to maintain the old ideology of 'separation from the world' in this changing environment" (17) is a basic principle that can cause differences of opinion about which people and influences are from the world and which guidelines serve to keep the community of believers separate from it. According to Cañás Bottos (2008), "attempting to separate themselves from modernity (as a proxy for understanding, practicing, and conceiving their separation from the world), the Old Colony incorporated its exclusion as a mark of belonging and difference from the world" (193). In trying to avoid the temptation of worldliness, it follows that technologies of communication and transportation-such as phones and rubber tires - have only been selectively incorporated in the more traditional and conservative Mennonite settlements in Belize. Maintaining a firm grip on the introduction of technologies is one way of keeping the mainstream world at bay.

However, the Ordnung is not only a reaction against the world surrounding a particular community; it is also a statement of the community's values and the hierarchy among them. Work is driven not only by profit motives, but by what Hawley (1995) - in her study of an Amish woman's business - describes as a

...plurality of purpose: Anna's goal of economic gain is intertwined with the performance of other basic social functions. Not only must she make business decisions that result in at least modest economic returns, but in doing so she must also express loyalty to the cultural group, affirm bonds of friendship for herself as an individual, commit to the rules of the Ordnung, and behave under the watchful eye of fellow church members. Implementing all these goals defines her success (Hawley 1995, 327).

These observations reaffirm how, in the Amish worldview, enterprise "provides a vehicle for economic development for both the individual and the community" (Hawley 1995, 327).

Both of these views of the Ordnung - as a response to the particular world around the community and as a reflection of the values held in the community - come into play in the case of technology use (or rather its selective use) among plain Anabaptists (Kok and Roessingh 2013; Kraybill 2010, 196; Roessingh and Boersma 2011). In these cases, a group must determine the extent to which the technology supports or challenges the values that guide its way of life. As Turner $(2014,165)$ explains in her study of Old Colony Mennonites in Southwestern Ontario, the 
navigation of religious values and economic pressures by Mennonites occurs "on their own terms." To understand the outcomes of such navigations, and what these "terms" might mean to community members, it is worth observing the external and internal pressures on the community and the context in which discussion occurs.

This attention to the contextual nature of technology use is in line with recent studies of technology use among Anabaptist groups, which theorize use of technology as socially contextualized (Ems 2014). This perspective

...begins from the assumption that all technology use is shaped by the social context of its creators and users. [...] It also introduces the opportunity to examine the role that values, politics, power, and ethics play in the adoption of technologies (Ems 2014, 48).

In her study of northern Indiana Amish business owners, Ems (2014) reports how they create "technological workarounds that allow them to abide by shared religious values while remaining competitive in the marketplace" (Ems 2014, 42). In her analysis, Ems frames Amish users of technology as "active and motivated to act by social norms, individual needs, and communal values" rather than as passive acceptants of "compromise" (Ems 2014, 49). The business owners in her study respond to both outside pressures from the market as well as from communityspecific religious values.

Concluding this section on Mennonite technology use, we may draw two conclusions. First, the navigation of Ordnung, technology use, and entrepreneurship inevitably involves the community. One theoretical tool that explicitly allows for this, possibly elucidating the connection between the individual and the social group, is social capital theory (Bourdieu 1986). Another way to allow for a non-deterministic view of technology use, social capital links community with individual, while remaining sensitive to the particular context of the case under study.

The second conclusion is that the constraints the Ordnung places on technology use - and the ways members use and interpret the constraints - can be seen as both a response to worldliness in a particular setting and as a symbol (Bourdieu 1986) of a community's commitment to the spiritual wellbeing of the entire group, above individual gain and community relations. Each community has its own struggles, points of discussion, and pressure. Study of a community Ordnung thus involves attention to both the specific religious context and the outer environments to which their Ordnungen respond. In our case, we study the Ordnung as an answer to the worldliness the Shipyard, Belize, context poses.

The brief introduction to Mennonites in Belize suggests how the world facing Shipyard might be different from that facing the Old Colony Mennonites and Amish in North America. Remaining separate from the world in developed economies involves living in proximity to urban centers and navigating pressures from a global economy (Ems 2014, 55; Driedger 2000). Anabaptist entrepreneurs face pressure to remain competitive. The complexities of such a 
situation push entrepreneurs to find creative ways to work according to their values. This characteristic of the environment, as a competitive place requiring technological adaptation, is also depicted by Turner (2014), who documents how in Canadian mainstream society, "digital knowledge is increasingly required to fill out tax forms, to access government immigration laws, to sign up for classes, to do banking, to find employment, and to work at many jobs" (172).

Different from their North American counterparts, the Mennonites of Shipyard do not face a highly competitive marketplace; their goods are in demand in Belize. The Mennonites were invited into the country for their expected contribution to the economy. The largest metropolitan area in Belize is Belize City, with around 60,000 inhabitants. The remoteness of Belize itself is captured well by Aldous Huxley, who wrote in his travel diary, "...if the world had any ends, British Honduras would certainly be one of them [...] it is not on the way from anywhere to anywhere else..." (Huxley 1949, 35). For the Ontario Mennonites whom Turner documents, a trying struggle is to balance the demands of the outside world with values held in the community. The struggle for the Old Colony Mennonites in Shipyard is a different one, as the following section indicates: namely, how to deal with internal religious diversity. Within Shipyard, members of the Old Colony church live alongside members of another Mennonite church, which has other interpretations of Scripture and another set of practical living rules.

\section{Shipyard Settlement: Conservatism and Diversity}

Shipyard is a settlement of approximately 3,400 inhabitants — of which 2,500 belong to the Old Colony church (Plasil 2015) — stretching over an area of approximately 17,000 acres in the Orange Walk District in northern Belize. Shipyard is largely dependent on agriculture, agriculturally-related labor, and small businesses. Dusty dirt roads lead up to the settlement, which gives visitors a first impression of uniformity. The symbolism of equality shows itself in many aspects of Shipyard's buildings. No building stands out for its size or color; church structures are plain. On individual compounds, families have, alongside their homes, a barn in which to store their buggy. One sometimes sees a van in front of the houses or compounds. Shipyard does not have a clear center - it is spread out over the flat land, divided into several districts known as camps. With its own school and administrative system, each camp reflects something of a little independent entity within the community.

The Old Colony forms the largest group in Shipyard. Families with about ten children are not uncommon. Due to this demographic reality, for some decennia Shipyard farmers have been confronted with a land shortage, which makes it difficult for young couples to find property. As a consequence, a split took place in the community in the 1970s, when many young couples of the Old Colony Mennonites moved away to Little Belize in the Corozal district and later to Indian Creek (near Shipyard).

Shipyard, Little Belize, and Indian Creek are all conservative Old Colony-based communities where technological change is very slow (Roessingh and Plasil 2006). The shared 
understanding of religious rules - referred to as the Ordnung - infuses many aspects of everyday life and agricultural practice. Rules are oriented toward avoiding worldliness. Mennonites in these communities use horse-drawn wagons because they are not allowed to drive automobiles. In the fields, they use tractors with iron tires, because rubber tires are forbidden (Plasil 2015). The Old Colony Mennonites have strict clothing codes, which make them very visible outside their community, not only for non-Mennonites and for other Mennonites but also for other Old Colony Mennonites from other communities.

Although the majority of Shipyard residents live according the rules and expectations of the Old Colony church, tensions are present beneath the surface. Followers of the Kleine Gemeinde church in Blue Creek, the progressive EMMC, and the Local Church also reside within the Shipyard community. The Local Church includes several families who were excommunicated for not living by the Ordnung and for being disobedient to the authority of the church council (Roessingh and Plasil 2006). Members of these denominations are regularly confronted with the multiple Ordnungen in the same settlement. Shipyard can thus be viewed as a place of religious contrast as well as conservatism, where differing interpretations of the Ordnung inform different styles of life.

The economy of Shipyard is based on agriculture and related trade and businesses, with most people making a living from farming, livestock, and agriculture-related labor. Beans, corn, rice, and soybeans are the main crops cultivated and prepared, together with cattle and chicken, for the Belizean market. Some people work in the slaughterhouses or one of the two feed mills. Those who are not employed in agriculture or in agriculturally related work make their living in furniture manufacturing, as electricians, as hardware or fabric shopkeepers, as dentists, or as mechanics within the Shipyard community. A few do outside wage labor in Blue Creek, Spanish Lookout, Orange Walk, or Belize City. Through different avenues of commerce, interactions with the outside world are many. The furniture business, chicken industry, and trade in other agricultural products - these all provide reason and opportunity for contact with outsiders. One such opportunity is in the meat trade.

\section{Practical Space: Expansion through Technology}

One of the Shipyard butchers, Peter Martin, has dealt successfully with his community's rules about using technology to widen his area of distribution. The Belizean electricity wires supply surrounding villages with power, but Shipyard settlers are not allowed to use this source. Because there is no central electricity within the community, certain electrical appliances — such as a refrigerator to cool meat - are powered by windmills and generators, which most families own. The rules forbid using a generator 24 hours a day; it must be turned off by sundown. Furthermore, one is not allowed to use a car, and rubber wheels are prohibited; most people drive along in horse-drawn buggies. Peter Martin, however, has managed to distribute his meat to places as far as San Ignacio, some 200 kilometers away along a rather rugged route that takes about three hours, if one has a car. 
Peter Martin manages to process and transport meat to a wide area because he uses certain technologies through the employment of non-Mennonite workers. He works with an outsider, a Belizean, who owns a pickup truck and transports the meat. After consulting the community elders, Peter also gained approval to use his generator 24 hours a day, on two days of the week, to keep the freshly-cut meat frozen. Peter is widely known for good quality meat and reliable delivery. Not only does the meat have to pass regular food quality controls, such as audits from HACCP (Hazard Analysis Critical Control Point), but all meat leaving his slaughter facility is also stamped by the BAHA (Belize Agricultural Health Authority). According to the Belizean law, no meat may be sold without the BAHA stamp.

Peter Martin's compound includes his home, a corral for the animals next to his home, and a slaughterhouse adjacent to the corral. His home is - as most of the buildings in Shipyard are - modest in exterior and surrounded by dirt roads. Peter selects the animals for the corral based on the orders for pork or beef customers send him.

The processing of a cow, from its entrance to the slaughterhouse to distribution or storage of its meat, takes no more than two hours and is accomplished by using mostly mechanical devices. Mennonite-bred cows enter the facility in a row. One-by-one, the cows are driven into a hold, where the cow is shot in the head. Immediately, its throat is slit so that blood runs out. The still-warm carcass is pulled up with an electrically operated chain, where it is systematically processed into a variety of pieces and products. These are put into boxes and moved into the cool box, waiting for the driver of the truck. The meat is loaded in the back of the truck and covered with plastic to make the journey to San Ignacio.

Peter Martin employs Mennonites, Ladinos, and other ethnicities. By using a nonMennonite Ladino truck driver, Peter is able to work around the strict rules governing motorized vehicles. Sometimes, Peter Martin or one of his sons drives along with the truck - riding as a passenger is not forbidden. This shows how some rules strictly upheld by the church may be flexible enough — if negotiated appropriately — to enable entrepreneurial activity outside the enclave.

Besides the selective use of technologies for energy and transportation, Peter also uses technology to communicate with customers outside the community. For instance, Thomas Burns, the owner of the meat shop in San Ignacio, Cayo district, is able to place an order with Peter on Saturday using his cell phone. Figure 1 shows a fragment of this communication. He sends a text message (through the cellular network) to Peter Martin's phone, which is registered to Peter's name, but is carried, charged, and operated by a non-Mennonite employee, Juan Avila. Juan travels to Shipyard on Saturday to communicate the received orders to Peter Martin. This means that Peter then prepares the required animals for slaughter, to start the butchering on Monday. On Monday morning, depending on the size of the orders, laborers arrive from neighboring regions. If the order is ambiguous, Peter asks Juan or his English-speaking son to verify the order by phone. In this way, Peter is able to order meat on Saturday and receive it on Tuesday, usually 
around 7 a.m. Payment is completed in cash or by check, and is received by Peter's son, who has accompanied Juan Avila to San Ignacio. Thanks to the careful use of a generator, a truck, and a cell phone, operated in part by his Ladino worker, Peter Martin's business is able to reach customers in a wide geographical range.

Figure 1: Cell Phone of San Ignacio Meat Shop Owner, Thomas Burns

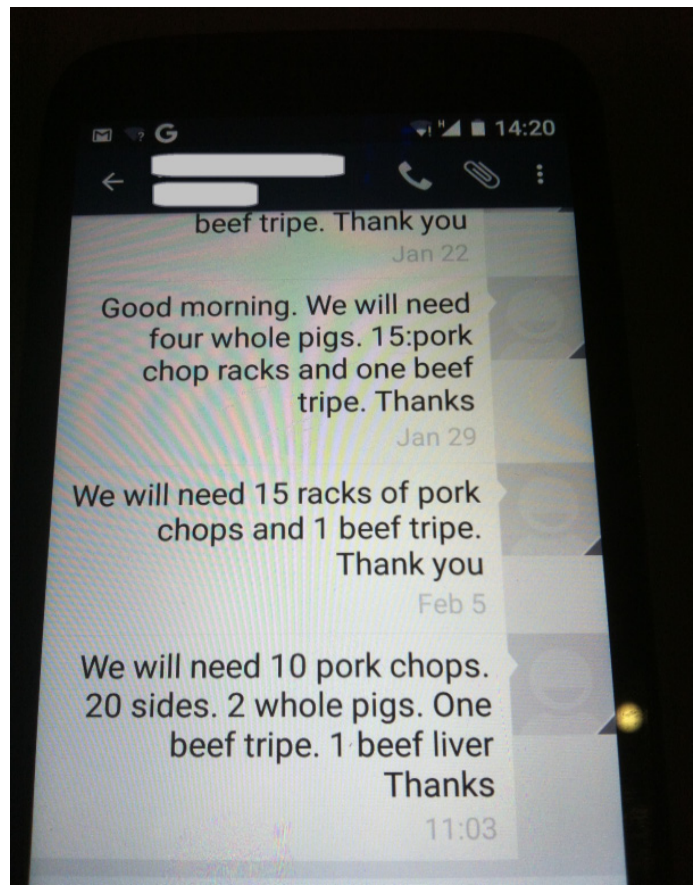

A screenshot from the cell phone of Thomas Burns, a meat shop owner in San Ignacio, showing a fragment of his correspondence with Peter Martin, a butcher in the Old Colony Mennonite settlement of Shipyard. Credit: Carel Roessingh

\section{Practical and Theoretical Considerations: From the Navigation of the Acceptable to Social Capital}

In this article, our primary interest is in the negotiations between one individual and the community's collective understanding of the church's Ordnung. Peter Martin, a member of the Old Colony Church, uses energy, transportation, and communication technologies to create geographical space for his business, reaching as far afield as San Ignacio. By using generators to cool his meat, a pickup truck to transport it, and a telephone to receive orders, Peter Martin can receive an order on Saturday and deliver it on Tuesday. Peter Martin is able to work within both the church system and the realm of the meat trade, with the opportunities and restrictions of each intersecting in his butchering practice. Furthermore, people from both within and without the Old Colony populate his world; through his network of distribution, he is regarded and treated as reliable.

This is worth noting for taking place inside a community that, in different ways, is facing pressure from within and without. Compared to other Belizean Mennonite settlements in more 
remote places (such as Springfield and Barton Creek), Shipyard's location near (bumpy) roads and rivers leaves it relatively more open to the outside world. Remaining far away from worldliness requires effort. The meat trade is only one example of this connectedness to the outside world. This adds to other tensions already present in the community, where representatives of the EMMC, the Local Church, and the Kleine Gemeinde reside. This leads us to consider mounting pressures on the Old Colony Church's Ordnung. In the midst of religious alternatives, Peter Martin stays put. At the same time, he takes the initiative to explore the world around him in terms of business opportunities.

In considering Peter Martin's daily work, what draws our attention is the finesse with which he gets his work done. Indeed, others have noted how initial restrictions in traditional communities "have resulted in ingenuity and technological innovation" (Ems 2014, 43; Loewen 2013; Loewen 2016). Those who study Mennonite settlements as outsiders often see the many eye-catching rules (Turner 2014). As outsiders, we watch Mennonites and we try to understand their lives; if we are honest, we often end up making a judgment of their conduct. Rules seem static realities to the outsider, while to the insider, rules are followed in dynamic circumstances. Our intention is not to point out anything in Peter Martin's work that we could call inconsistent, since often what looks like a paradox from a distance is perfectly workable for those dealing with the matter in close proximity. Peter Martin's repertoire of practices, together with his stable position as an accepted member of the community, lead us rather to consider the internal subtleties that comprise what is permissible - which we admit to remaining largely unaware. We are led to entertain a more dynamic, creative understanding of this man's relation to the Ordnung and how he succeeds in making "plain" those practices that an outsider might consider remarkable. It is on this theme of the Ordnung's apparent restriction-but yet the space that can be found in it - that we offer some concluding considerations. To do so, we employ the concept of social capital (Bourdieu 1986; Portes 2010).

Social capital is a way to account for economic outcomes by looking at social ties, and to account for the collective benefits that derive from practices of trust and cooperation within specific groups. Portes $(2010,27)$ defines social capital as "the ability to gain access to resources by virtue of membership in networks or larger social structures." Analyses in terms of social capital account for how some communities can be socially rich while possessing little worldly wealth. Portes and Sensenbrenner (1993, 1323-25) distinguish four resources that yield social capital: value introjection, bounded solidarity, reciprocity transactions, and enforceable trust. As we argue briefly below, ${ }^{3}$ these four resources play a role in the Old Colony Mennonite community of Shipyard, particularly in the way entrepreneurship emerges and claims space within the apparent limits of the community's religious rules.

Value introjection refers to the extent to which community members have internalized shared norms. These norms - and their assumed presence in the minds of others - then function as a resource (Portes 2010) that people can call upon. Old Colony community members have established a strong sense of value introjection through which they share commitment to the 
group's beliefs and values - among others, through their strong ties within and between families in the colony, their separation from the world, their shared religious ideology, and their view of the larger society and their own church. The benefits yielded by such shared beliefs are not universal. The group must be delimited. The Old Colony Mennonites are a migrant group in Belize that locals consider an "other" group. This sense of otherness stimulates the development of stronger ethnic and religious ties_-bounded solidarity — within the Old Colony Mennonite community.

Reciprocity transactions refer to exchanges of specific resources among community members (Martes and Rodriguez 2004). Exchanges provide Mennonites with support in the form of jobs, construction material for building barns and houses, aid, and care for the elderly and disabled, or as Hedberg (2013) describes it:

No matter if you are rich or poor, your ability to carry out the Old Colony way of life determines to what extent fellow community members consider you to be participating in the generalized reciprocity of the colony, contributing to maintenance of community and thus to the Old Colonists' common concern (102).

The Mennonites in general share a strong awareness of their own history, which adds to intra-group solidarity and, consequently, enforceable trust. This deep sense of trust, backed by the means to enforce it, is embedded in the Old Colony church regulations and contributes to strong social cohesion.

With these four resources - value introjection, bounded solidarity, reciprocity transactions, and enforceable trust - community life at Shipyard is enriched by the presence of the Ordnung. Its parameters enable values to be shared among a bounded people and physical resources to be exchanged on the basis of trust. When we look at Peter Martin's selective use of technology, we arrive at a central paradox: it is because of these limitations - and thus the capital that they yield to him - that Peter Martin is able to stretch the boundaries of his business. By abiding by the rules of the church, he has established a name such that the church trusts him to handle technology in an acceptable way. His central place within the Shipyard community, as an employer and supplier, gives him access to social capital. This social capital gives him space to expand. In a sense, he uses the boundaries to extend the boundaries - not too far, of course, and within limits. Ryman (2004) points out that "there is a potential cost of social capital that is related to the opportunity that one must forgo to conform to the group norms and remain a member of the community" (Ryman 2004, 206).

These two sides of social capital — its parameters and its space — can be captured by way of a saying that we have in The Netherlands: "Steek je hoofd niet boven het maaiveld uit" (literally: "Don't raise your head above the surface of the field") — that is to say, abide by the rules, do not extend yourself beyond them, or you could run into trouble. To the Dutch visitor to Belize, there is an odd familiarity to Shipyard's modest setting and way of life, an echo, perhaps, 
of their historical roots. Before their many migrations through Poland, Russia, Canada, and Mexico, ultimately bringing them to Belize, those who are commonly called Russian Mennonites historically hail from the Northern Netherlands and Germany. At the same time, descriptions of economic practices at Shipyard in terms of social capital give a sense that life is rich enough under the cornfield. Seen in this light, Peter Martin is someone who has found the space to flourish under the field's surface.

\section{Conclusion}

Traditionally, research on technology use by Mennonites and Amish businesspeople has been based on observations in North America. This makes recent academic studies of Old Colony Mennonite communities in Bolivia (Hedberg 2007), Argentina (Cañás Bottos 2008), Mexico (Quiring 2003), Paraguay (Dana and Dana 2007), and this present study worth noting, in a field where, theoretically, the importance of context is often stressed. A community's selective use of technology shows us the particular world in which a settlement is situated. This paper has taken as its focus Shipyard settlement in Belize and the Ordnung of the Old Colony church as it relates to technology. We have documented one man's business dealings with the inside and outside world. Peter Martin's case gives an insight into what this navigation might look like in a place that is geographically isolated and religiously diverse. Inside the Shipyard settlement, frictions are present. Decisions on technology use play a role in the enforcing of the Ordnung, in a context of religious alternatives and mounting pressures on the Old Colony church in Shipyard. Future studies of this theme could research these connections between religious tension and selective use of technology.

\section{Endnotes}

${ }^{1}$ Carel Roessingh (1951) studied cultural anthropology and received his Ph.D. at the University of Utrecht. His Ph.D. research was on the Belizean Garifuna. His central research interest is now religious entrepreneurs, focusing on the organizational activities of the Mennonites in Belize and Central America. Contact information: Vrije Universiteit Amsterdam, Faculty of Social Sciences, Department of Organization Sciences, De Boelelaan 1081, 1081 HV Amsterdam, The Netherlands; c.h.roessingh@vu.nl; +31 205986729

${ }^{2}$ Daniëlle Bovenberg (1992) obtained her M.Sc. in Culture, Organization, and Management at the Vrije Universiteit Amsterdam. Her interest centers on the use of technology in work, and its role in shaping conceptions of craftsmanship and healthcare, and of the people involved in these pursuits. Contact information: Vrije Universiteit Amsterdam, Faculty of Social Sciences, Department of Organization Sciences, De Boelelaan 1081, 1081 HV Amsterdam, The Netherlands; d.e.bovenberg@vu.nl; +31 205986740

${ }^{3}$ A lengthier version of this argument can be found in Roessingh (2013). 


\section{References}

Anderson, Cory. 2013. "Who Are the Plain Anabaptists? What Are the Plain Anabaptists?" Journal of Amish and Plain Anabaptist Studies 1(1):26-71.

Bourdieu, Pierre. 1986. “The Forms of Capital.” Pp. 241-258 in Handbook of Theory and Research for the Sociology of Education, edited by J. Richardson. New York, NY: Greenwood Press.

Cañás Bottos, Lorenzo. 2008. Old Colony Mennonites in Argentina and Bolivia. Leiden, The Netherlands: Brill.

Dana, Leo-Paul, and Teresa Dana. 2007. "Collective Entrepreneurship in a Mennonite Community in Paraguay." Latin American Business Review 8(4):82-96. https://doi.org/10.1080/10978520802114730

Driedger, Leo. 1958. "From Mexico to British Honduras.” Mennonite Life 13(4):160-66.

Driedger, Leo. 2000. Mennonites in the Global Village. Toronto, ON: University of Toronto Press. https://doi.org/10.3138/9781442677234

Ems, Lindsay. 2014. "Amish Workarounds: Towards a Dynamic, Contextualized View of Technology Use.” Journal of Amish and Plain Anabaptist Studies 2(1):42-58.

Everitt, John. 1983. “Mennonites in Belize.” Journal of Cultural Geography 3(2):82-93. https://doi.org/10.1080/08873638309478597

Gingerich, James N. 1986. "Ordinance of Ordering: Ordnung and Amish Ministers Meetings, 1862-1878." Mennonite Quarterly Review 60(2):180-99.

Hawley, Jana. 1995. "Maintaining Business While Maintaining Boundaries: An Amish Woman's Entrepreneurial Experience.” Entrepreneurship, Innovation, and Change 4(4):315-28.

Hedberg, Anna Sophia. 2007. Outside the World: Cohesion and Deviation among Old Colony Mennonites in Bolivia. Uppsala, Sweden: Uppsala University Press.

Hedberg, Anna Sophia. 2013. "Speaking of 'Peter Money' and Poor Abraham: Wealth, Poverty, and Consumption among Old Colony Mennonites in Bolivia." Journal of Mennonite Studies 31:87-104.

Huxley, Aldous. 1949. Beyond the Mexique Bay. A Traveller's Journal. London, UK: Chattoo \& Windus. 
Kok, Anne, and Carel Roessingh. 2013. "Where 'God Sleeps at Night': Integration, Differentiation, and Fragmentation in a Mennonite Colony." Journal of Mennonite Studies 31:167-82.

Koop, Gerard. 1991. Pioneer Years in Belize. Belmopan, Belize: Published by G.S. Koop.

Kraybill, Donald. 2010. Concise Encyclopedia of Amish, Brethren, Hutterites, and Mennonites. Baltimore, MD: Johns Hopkins University Press.

Kraybill, Donald, and Carl Bowman. 2001. On the Backroad to Heaven: Old Order Hutterites, Mennonites, Amish, and Brethren. Baltimore, MD: Johns Hopkins University Press.

Kraybill, Donald, and Marc Olshan. 1994. The Amish Struggle with Modernity. Hanover, NH: University Press of New England.

Kroeker, Wally. 2005. An Introduction to the Russian Mennonites. Intercourse, PA: Good Books.

Loewen, Royden. 1993. Family, Church and Market: A Mennonite Community in the Old and the New Worlds, 1850-1930. Urbana, IL: University of Illinois Press.

Loewen, Royden. 2006. Diaspora in the Countryside: Two Mennonite Communities and MidTwentieth-Century Rural Disjuncture. Toronto, ON: University of Toronto Press. https://doi.org/10.3138/9781442627871

Loewen, Royden. 2013. Village among Nations: “Canadian” Mennonites in a Transnational World, 1916-2006. Toronto, ON: University of Toronto Press.

Loewen, Royden. 2016. Horse-and-Buggy Genius: Listening to Mennonites Contest the Modern World. Winnipeg, MB: University of Manitoba Press.

Martes, Ana, and Carlos Rodriguez. 2004. "Church Membership, Social Capital, and Entrepreneurship in Brazilian Communities in the U.S.” Pp.171-201 in Ethnic Entrepreneurship: Structure and Process. International Research in the Business Disciplines, Vol. 4, edited by Curt Stiles and Craig Galbraith. Amsterdam, The Netherlands: Elsevier.

Plasil, Tanja. 2015. "Community and Schism among the Old Colony Mennonites of Belize: A Case Study." Journal of Mennonite Studies 33:251-73.

Plasil, Tanja, and Carel Roessingh. 2006. "Food and the Community: The Role of Sharing a Meal among the Mennonites of Shipyard, Belize.” Belizean Studies 28(1):42-56.

Portes, Alejandro. 2010. Economic Sociology: A Systematic Inquiry. Princeton, NJ: Princeton University Press. https://doi.org/10.1515/9781400835171 
Portes, Alejandro, and Julia Sensenbrenner. 1993. "Embeddedness and Migration: Notes on the Social Determinants of Economic Action.” American Journal of Sociology 98(6):132051. https://doi.org/10.1086/230191

Quiring, David. 2003. The Mennonite Old Colony Vision: Under Siege in Mexico and the Canadian Connection. Steinbach, MB: Crossway Publications, Inc.

Quiring, Walter. 1961. “Mennonites in British Honduras.” Mennonite Life 16(1):10-13.

Redekop, Calvin. 1969. The Old Colony Mennonites. Dilemmas of Ethnic Minority Life. Baltimore, MD: Johns Hopkins University Press.

Redekop, Calvin, Stephen Ainlay, and Robert Siemens. 1995. Mennonite Entrepreneurship. Baltimore, MD: Johns Hopkins University Press.

Roessingh, Carel. 2013. "Small-Scale Farmers in Springfield Colony, Belize.” Mennonite Quarterly Review 87(4):574-83.

Roessingh, Carel and Kees Boersma. 2011. "We Are Growing Belize': Modernisation and Organizational Change in the Mennonites Settlement of Spanish Lookout, Belize." International Journal of Entrepreneurship \& Small Business 14(2):171-89. https://doi.org/10.1504/IJESB.2011.042718

Roessingh Carel, and Amber Schoonderwoerd. 2005. "Traditional Farmers or Modern Businessmen? Religious Differentiation and Entrepreneurship in a Kleine Gemeinde Mennonite Community in Belize." Journal of Developmental Entrepreneurship 10(1):65-77. https://doi.org/10.1142/S1084946705000069

Roessingh, Carel, and Tanja Plasil. 2006. "From Collective Body to Individual Mind: Religious Change in an Old Colony Mennonite Community in Belize." Journal of Mennonite Studies 24:57-74.

Roessingh, Carel, and Tanja Plasil (eds.). 2009. Between Horse \& Buggy and Four-Wheel Drive: Change and Diversity among Mennonite Settlements in Belize, Central America. Amsterdam, The Netherlands: VU University Press.

Ryman, Joel. 2004. "Are You at Peace with God and Your Neighbour? Cultural Resources and Restraints on Mennonite Entrepreneurship.” Pp. 203-17 in Ethnic Entrepreneurship: Structure and Process. International Research in the Business Disciplines, Vol. 4, edited by Curt Stiles and Craig Galbraith. Amsterdam, The Netherlands: Elsevier.

Sawatzky, Harry. 1971. They Sought a Country: Mennonite Colonization in Mexico. Berkeley, CA: University of California Press. 
Scharinger-Plasil, Tanja. 2004. Gemeinschaft und Meidung; Community Forming and Differentiation among the Excommunicated People of the Shipyard Mennonite Colony in Northern Belize. M.A. Thesis. Amsterdam, The Netherlands: University of Amsterdam.

Scott, Stephen, and Kenneth Pellman. 1990. Living without Electricity. Intercourse, PA: Good Books.

Turner, Kira. 2014. "Living on the Edge: Old Colony Mennonites and Digital Technology Usage." Journal of Amish and Plain Anabaptist Studies 2(2):165-85.

Zimmerman Umble, Diane. 1996. Holding the Line: The Telephone in Old Order Mennonite and Amish Life. Baltimore, MD: Johns Hopkins University Press. 